\title{
Ethnographies of entrepreneurs, business associations and rentier capitalism in Africa Introduction
}

Thomas Bierschenk and José-María Muñoz

\section{OpenEdition \\ Journals}

Electronic version

URL: https://journals.openedition.org/anthropodev/1437

DOI: 10.4000/anthropodev. 1437

ISSN: 2553-1719

Publisher

Presses universitaires de Louvain

\section{Printed version}

Date of publication: 31 December 2021

Number of pages: 9-28

ISBN: 978-2-39061-188-2

ISSN: 2276-2019

\section{Electronic reference}

Thomas Bierschenk and José-María Muñoz, "Ethnographies of entrepreneurs, business associations and rentier capitalism in Africa", Anthropologie \& développement [Online], 52 | 2021, Online since 31 December 2021, connection on 08 December 2022. URL: http://journals.openedition.org/ anthropodev/1437 ; DOI: https://doi.org/10.4000/anthropodev.1437

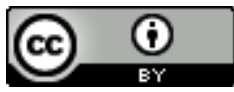

Creative Commons - Attribution 4.0 International - CC BY 4.0 https://creativecommons.org/licenses/by/4.0/ 


\section{Ethnographies of entrepreneurs, business associations and rentier capitalism in Africa}

Introduction

Thomas Bierschenk*, José-María Muñoz ${ }^{* *}$

\section{Introduction, research question, theses}

Twenty years after The Economist called Africa "the hopeless continent" (13 May 2000), the view has profoundly changed. At least until the pandemic, the effects of which are unclear at the present time, the dominant mood had been decidedly positive, one of "Lions on the Move". This euphoria was supported by perceived dynamics in economic fields like agriculture, mobile phones, microfinance and supermarkets (with regard to agricultural supply chains), as well as social transformations such as urbanisation, educational expansion, improved health care and the rise of the middle classes. In this context, the focus of development policy has shifted, with Private Sector Development (PSD) as the dominant paradigm.

Against this background, this issue aims to explore ethnographically the links between businesspeople and their associations, private sector support from the state and international development agencies and emergent (or not) capitalism in Africa. At an analytical level, our contributors study the relationship between business and politics in their specialist countries, while at a policy level, they seek to gauge the real-life effects of PSD, and in particular what kind of "business" is described and celebrated as "emerging".

Our authors all take a critical distance from the current neoliberal idealised notions of entrepreneurs as the central powerhouse of economic development in Africa, and from the belief in entrepreneurship's principally innovative nature (Akinyoade et al., 2017). The research presented here implies that business and politics are not strictly separate spheres, as the literature on business associations often suggests, but that in line with insights from political anthropology, we should assume the existence of a single social field of interwoven discourses and practices in which international actors play an

\footnotetext{
* Johannes Gutenberg-Universität, Germany; biersche@uni-mainz.de

** University of Edinburgh, United Kingdom; j.munoz@ed.ac.uk
} 
important role. A significant proportion of African businesspeople operate as rentiers, a term we will return to later. Our authors also show that the paradigm of PSD should be understood as a travelling model that is not necessarily able to change existing legacies and logics, but rather is often captured by them. Although PSD creates a variety of institutions and promotes individual entrepreneurs, the question of how much economic development it actually produces remains an open one.

The countries looked at in this issue are, in alphabetical order, Benin (A. Badou and T. Bierschenk), Cameroon (G. Amougou), Mozambique (A. Manhiça), Nigeria (A. Bud) and Togo (C. Vampo), while S. Cissokho's contribution is not nationally focused, referring as it does to West African regional organizations and actors. This is a somewhat random selection reflecting the response to our original call for papers and the review process. As a result, while Nigeria, which accounts for about $40 \%$ of SSA's GDP, is represented here, Ethiopia and Rwanda - which are often treated as star PSD performers by development agencies - are not. In other words, this issue does not claim to be representative of the entire continent, which would be a somewhat dubious objective. In what for the editors was an unexpected response to our wide-ranging call for papers, the majority of our contributions deal with business associations (including one of women entrepreneurs in Togo, see Vampo; one at a regional West African level, see Cissokho). The two contributions that are not focused on business associations deal with different types of entrepreneurs in Nigeria (Bud) and Cameroon (Amougou). G. Amougou, A. Badou and T. Bierschenk, and A. Manhiça also explicitly address the reality of PSD policies.

\section{Private sector development and the heroisation of the entrepreneur}

In recent decades, the discourse of international development agencies has placed considerable emphasis on the reform of public institutions, as indicated by the prominence of the "good governance" agenda. More recently, this has been supplemented by explicit promotion of the private sector. PSD has become both a separate field of development policy and a topos that has been taken up by development-economic research. As a policy paradigm, it involves not only the promotion of small and medium enterprises, but also highly controversial programmes, especially the World Bank's Doing Business (DB) initiative (2004). As a result, many development agencies, including NGOs, have been enrolled - at times reluctantly - into programmes to promote entrepreneurship and small-scale capitalism (see also Rubino, in the varia section of this issue).

The PSD paradigm and the specific agendas associated with it nevertheless have peculiar blind spots: how much private sector development have the programmes actually brought about, what is the nature of the emergent enterprises, and what is their position in the societal set-up of their respective countries? Empirically, the answers to these questions have remained remarkably nebulous. While lively debates on the meaningfulness and the ideological foundations of the DB initiative are under way, there has been noticeably less questioning of the kind of "business" claimed by the countries that have been successfully described as "emerging" and what this says about the changing (or unchanging) character of African political economies. 
Efforts by multilateral and bilateral donors to advocate for "business environment reforms" or to restructure specific economic sectors - often through the creation or strengthening of business associations - or the evolving arrangements for periodic government-private sector forums provide opportunities for innovative ethnographic research. The promotion of entrepreneurship through training and technical and financial support has been the focus of ethnographic contributions (Elyachar, 2005), but these programmes are only a small component of a much larger field of intervention.

Interest in the conditions of catch-up economic development through a lens pointed at entrepreneurs has been pursued with intensity in economic journalism. A 2011 cover of The Economist entitled "Africa Rising" (3 December 2011) has become emblematic of Africa's position as the last frontier of capitalism. In this economic journalistic literature, individual African entrepreneurs have recently been celebrated as a vanguard of economic and social development in Africa, proposing the notion of "Africapitalism". One of the most prominent among them, T. Elumelu, proclaimed at the annual Entrepreneurship Forum that "Africapitalism is taking centre-stage" ${ }^{1}$. Other prominent entrepreneurs like Y. Kabongo have joined in and declared themselves to be radical "Africapitalistes" (Le Monde, 25 June 2019: 15). The mood turned decidedly Afro-optimist, at least for a while.

In other words, a heroic figure of the entrepreneur has re-emerged from development policy discourses since around 2010 - one that, as these discourses all do, not only describes social dynamics in the real world, but also seeks to conjure up their existence (Chapus et al., 2021). Paradigms of this hype are publications like J.M. Severino and J. Hajdenberg (2016, quoted from the abstract) who speak of "a booming private sector, a range of dynamic SMEs and a new generation of entrepreneurs; often young, well trained and qualified, and frequently coming from the diaspora. From agroindustry to telecommunications, from the construction sector to health, tourism or energy, a new economy is emerging in Sub-Saharan Africa".

The PSD approach is a reaction to the dashed hopes attached to the earlier paradigms of structural adjustment and good governance that had been proposed by national and multilateral aid agencies and NGOs as a solution to the problems of poverty and stagnating economic performance across Africa. A central assumption of this neoliberal approach that was initially favoured by most donors - that the government's role when it comes to industrial development must be limited to providing the "right" environment for the private sector to grow - had been confounded. This view had been based on an expectation that the state's retreat to a regulatory role would automatically unleash market forces and capitalist competition from those entrepreneurs, whose energies had been stifled by an overbearing state.

However, it turned out that privatisation did not lead to the automatic emergence of a flourishing private sector. In response, some economists argued that governments needed

\footnotetext{
${ }^{1}$ See: https://www.tonyelumelufoundation.org (accessed September 2019).
} 
to actively engage in industrial policy (Asche, 2021). Development, the argument goes, requires a structural transformation of the economy that cannot be triggered by the private sector alone; it requires public intervention and sustained support for new productive sectors and the entrepreneurs operating in them. It was realised that a capitalist market does not automatically follow the withdrawal of the state; rather, it must be actively created. The private sector must be actively developed; it must become the direct object of intervention.

In this sense, the PSD paradigm that has been emerging since the early 2000s has tried to learn the lessons from the utopian naivety of the preceding structural adjustment programmes and good governance agendas. It is thus assumed that entrepreneurs are heckled from two sides, on the one hand by their social milieu, and on the other by business-unfriendly state structures. This brought two issues to the centre of policy efforts and the accompanying research: the so-called business system, the institutional context in which entrepreneurs operate (Pedersen and McCormick, 1999) - including business associations, which we will return to below - and the psychosocial characteristics of (African) entrepreneurs. We will deal with the second aspect first.

According to The Economist of 2 July 2016, referring to research by the World Bank, Africa has more entrepreneurs (most of whom are self-employed) than the rest of the world but fewer enterprises (per population only one eighth of the OECD and one quarter of Asia). In fact, in the paeans to the entrepreneur we have referred to, it is often claimed that there are huge emerging markets on the demand side due to urbanisation and the rising middle classes, while demographic growth and educational advances create vast pools of young entrepreneurs ready to profit from these opportunities. The creative and innovative entrepreneur, following Schumpeter, is celebrated as a central actor in economic development. Therefore, one task of private sector development is to support, if not create, this "good" entrepreneurial ethos that is assumed to be lacking in Africa (the other is to create a conducive institutional environment, such as business associations). There are clear echoes of the psycho-sociological variants of the modernisation theories of the 1950s and 1960s, which saw a "traditional" mindset as one of the "barriers" to modernisation and development (à la McClelland, 1961; for its application to Nigeria after independence, see LeVine, 1968). This basic assumption of the lack of entrepreneurial ethos also explains why the PSD programmes lay so much emphasis on training.

The normative topos of the heroic entrepreneur is not peculiar to Africa, but the expression of a global neoliberal trend. Measures such as training sessions on how to draw up a business plan, competitions for start-ups, setting up business incubators and creating innovation hubs are travelling models that are often imported into Africa in ready-to-use formats. Since the 1980s, there has also been a considerable worldwide expansion of "entrepreneurship research", as witnessed, for example, by the growing number of university chairs. Topics of research and teaching include personality traits, "entrepreneurial ecosystems" (business systems), and special forms of entrepreneurship such as social entrepreneurs and ethnic entrepreneurs. In other words, PSD might be another case 
of solutions looking for problems, which has been identified as a feature of development policy (Naudet, 1999).

Furthermore, heroism and a normative view of the good entrepreneur are inherent in the notion of the entrepreneur itself which in most cases is borrowed from Schumpeter (1947), who emphasised "creative achievement", innovation, and the entrepreneurial taking of "risk". This becomes particularly apparent if we look at how the term is translated in different languages. In German, for example, the term is Unternehmer, a translation of the English "undertaker", which is itself translated from the older French entre-preneur. Unternehmer are simply social actors who are engaged in private business and as such have a legal existence. They are not employed by others but do business for their own account. From the point of view of economics, they combine the production factors of capital, labour and land in order to make a profit. From a sociological standpoint, the notion of Unternehmerschaft can also refer to a social class, a point we will return to below. In any case, Unternehmer lacks the emphatic, heroic and normative ring it has in English. A more prosaic translation, therefore, would be businessperson, or in French, homme/femme d'affaires.

As for Africa, many anthropological studies have raised doubts about whether African businesspeople really lack an entrepreneurial ethos (Ellis et Fauré, 1995; Fauré and Labazée, 2000; Warnier, 1993). The economist P. Kilby (2003: 23), whose long-term research in Nigeria in the late 1960s and early 1970s offered a vivid portrait of the constraints businesspeople faced in the decades after independence, noted the irony in the fact that in contexts like the ones he studied, the aspects of the managerial role Schumpeter singled out as less entrepreneurial ("mere management") were often decisive when accounting for entrepreneurial success. A look at the emic use of the term entrepreneur is also revealing. As an index of its spread and semantic range, consider the extensive use of the French term entrepreneur in conversations in Fulfulde specifically to designate public contractors, which J.-M. Muñoz (2018: 64-92) documented in northern Cameroon in the mid-2000s. In this context, the moniker stigmatised contractors, associating them with the extralegal and illegal arrangements on which a rigged game that allowed civil servants to enrich themselves was premised, and with the resulting inflated budgets and substandard works that put precious improvements to public infrastructure and services in jeopardy. Similarly, in Benin entrepreneur is a synonym for homme/femme d'affaires, and is predominantly used in the construction sector, where most work is done for the state (Badou and Bierschenk, this issue).

In conclusion, the challenge as we see it is to avoid the notion of entrepreneurship becoming a straightjacket that prevents us from doing justice to the complexities and entanglements that shape the work of businesspeople and business organizations.

\section{Anthropology and the study of entrepreneurs in Africa}

There is now a largish body of literature produced by anthropologists on business and businesspeople, and major companies have become an established locus of ethnographic 
attention in a broad range of settings (Welker, Partridge and Hardin, 2011). Business anthropology is an expanding field, with journals like the Journal of Business Anthropology, partly overlapping with the anthropology of organizations (which started out as business anthropology, see Wright, 1994). This may be less the case in Africa, where studies of incorporated businesses have been largely restricted to sectors with a significant presence of multinational actors, such as the extractive industries (Kapferer, 1972; for two noteworthy recent monographs, see Rajak, 2011, and Rubbers, 2013). This state of affairs derives from a variety of factors, the most obvious of which may be the comparatively small numbers of registered companies in most African countries. Indeed, the informalisation of economic activities has been a thread running through Africanist economic anthropology. This informalisation has been interpreted both in terms of longue durée historicity and as the outcome of global economic trends and policy paradigms from the 1970s to the present day (Guyer, 2004).

It is hardly surprising, then, that the corpus produced by anthropologists on African business networks and actors is richer than that on companies, as state-of-the-art overviews have shown since the 1990s (Labazée, 1991; see also the importance of anthropologists among the contributors to a major inter-disciplinary synthesis of the time, Ellis and Fauré, 1995). This intellectual lineage lives on in recent ethnographic research, including two monographs that are exemplary for the effort they make to reconstruct the things, people, networks and companies that make pharmaceuticals in Nigeria (Peterson, 2014) and pagnes in Togo (Sylvanus, 2016) what they are.

Beyond these concerns, anthropologists often use a very wide notion of entrepreneurs and entrepreneurship that goes far beyond the economy in the strict sense, following early attempts by F. Barth (1963) and others (e.g. Evers, 1964), who were clearly inspired by modernisation theory. Among more recent examples of anthropologists extending this notion without necessarily subscribing to modernisation theory, the thematic issue of this journal that appeared in 2009 as $n^{\circ} 29-30$ with the title "Entrepreneurs and Enterprises in Search of Norms" included contributions on church leaders, educational entrepreneurs, and film directors, as well as on land speculation and child trafficking (Saint-Lary, 2009). ${ }^{2}$ U. Röschenthaler and D. Schulz (2019) work with an equally broad concept of "cultural entrepreneurs", oscillating between the "cultural sector" in the narrow sense (video, media, and music), and a broader definition according to which entrepreneurs can also be found in fields like religion, prostitution, education, and politics. "Entrepreneurial abilities, it is said, are shown by numerous African actors", and, in a clear nod to Schumpeter, the term is understood to mean "individuals who quickly perceive the chances of the moment and seize novel opportunities to initiate new forms of generating income" (Röschenthaler and Schulz, 2019: 1). In this way, however, the concept of the entrepreneur tends to coincide with that of the active social actor, a semantic extension we believe to be not unproblematic. Some authors have therefore proposed speaking of "entrepreneurial

2 See: https://apad-association.org/project/29-30-entrepreneurs-et-entreprises-en-quete-de-normes (accessed July 2021). 
Africans" rather than African entrepreneurs (Ochonu, 2018). Our contributions, in contrast, focus on the economic sphere in a narrower sense.

\section{Capitalism and business associations}

While development policy debate and practice have increasingly focused on private sector promotion over the last twenty years, the concept of capitalism has made a remarkable comeback in the social sciences. The term had been somewhat relegated to the background since the 1968 and post-1968 debates, as it seemed to many scholars to be too broad, totalising and vague, or too value-laden, ideological, and polemical. Currently, however, the notion of capitalism is receiving a degree of academic attention it has not enjoyed for a long time, and it is increasingly once again being understood as a key term for global diagnoses of the contemporary condition, leading some authors to speak of a Capitalocene. This trend is particularly evident in historical studies, where corporate bosses, bankers, and financiers - in other words the people who play protagonist roles in running the economy - have become the subject of empirical studies (Kocka, 2016). As for political economy, we find the Varieties of Capitalism debate which, in the wake of the capitalist transformation of the Soviet Union and the socialist states of the Eastern Bloc, seeks to theorise different political configurations of capitalism ("liberal market economies" vs. "coordinated market economies", "Rhenish capitalism" vs. "Anglo-Saxon capitalism", etc.) (Hall and Soskice, 2001). This line of research has focused more on systemic aspects than on actors, thus drawing a picture of capitalism without capitalists (Puente and Schneider, 2020).

The revival of the capitalism perspective has also reached African studies. ${ }^{3}$ However, social scientists and historians with an interest in capitalism as a guiding term for research on Africa have predominantly been interested in labour constitutions or, in connection with the issue of emerging middle classes, in the consumption side of economic development, using the term consumer capitalism (Meagher et al., 2017; Eckert, 2016; Lentz, 2017; Dolan and Gordon, 2019). With few exceptions, the Varieties of Capitalism debate has so far bypassed Africa, while Africapitalism has remained largely under-theorised (Ouma, 2019). The study of entrepreneurs in Africa, to which we referred above, has largely taken place without the concept of capitalism. This is all the more remarkable because capitalism can be combined with quite different labour constitutions in different historical contexts, and can certainly be embedded in non-capitalist social relations which, incidentally, must probably be considered to be the macro-historical default situation (Kocka, 2017). The existence of entrepreneurs or enterprises that have private property and disposal rights, on the other hand, is a basic definitional condition for the existence of capitalism. Although the term is barely expressly used by our contributors, we also understand this thematic issue to be a contribution to the debate on capitalism and Africa.

\footnotetext{
${ }^{3}$ See : https://roape.net/category/capitalism-in-africa (accessed July 2021).
} 
In the background of this conceptual and discursive development towards PSD and capitalism lurks the old question of the conditions of catch-up economic development in Africa. The last time the question of the overall social outcome of economic development was systematically addressed in African studies with reference to the concept of capitalism was in the so-called Kenya Debate at the end of the 1970s and beginning of the 1980s, its smaller counterpart in Nigeria studies, and its precursor, which is practically unknown outside the Francophone world, on West Africa (Kitching, 1985; Forrest, 1994; Amin, 1967, 1969). Here, based on empirical research, systemic questions were asked about the emergence of an African agrarian and industrial capitalism whose social engine - an indigenous entrepreneurship - was to differ from a pure comprador bourgeoisie in the dependency theory sense. In this context, the shaping of state structures and policies by certain socio-economic interests was thematised and empirically examined for some institutions.

Against this background, the contributions in our issue also address businesspeople as a social class, not so much in an objective sense but rather concerning their political consciousness and practices: are the entrepreneurs in the countries covered here aware of their existence as a class, how do they define their interests, and how do they pursue them? In old Marxist language, the question is whether entrepreneurs are, at least in some places, in the process of becoming a "class unto themselves" (Lukács, 1970). Here, our contributors follow in the footsteps of ground-breaking anthropological research (McGaffey, 1987). With this focus on the forms of social organization and organized political influence of entrepreneurs, the question of the representation of their interests comes into focus. Business associations, with their interconnectedness with the state and development agencies, are a dominating empirical topic of this issue (Badou and Bierschenk, Cissokho, Manhiça, Vampo). The question of interest here is not the existence of these organizations per se, but their internal constitutions and political practices.

While organized business interests in Africa have a long history, present-day associations in most countries have many of the features of the specific travelling models (see below) that have been promoted by bilateral and multilateral funders since the 1990s. In many ways, business associations (BA) have become a nexus for the centrifugal forces that govern relations between aid donors and recipients.

The oldest existing organizations are the national chambers of commerce, a continuation of their colonial antecedents, which in most cases African businesspeople were only allowed to join after World War Two. There were considerable differences in the legal frameworks governing chambers, most noticeably between common law and civil law countries. In the former, they were self-organizing bodies with voluntary membership; in the latter, they tended to be under closer government supervision and membership came automatically with registration in the business registry. These two types could vary considerably internally, however, and in the one-party regimes prevailing in most countries during the early decades of independence, they tended to be used as tools by political leaders to demobilise businesses politically, regardless of their legal status. In many countries, the ground regained by freedom of association in the late 1980s and 
1990s led to reforms of corporatist organizations like chambers of commerce and shippers' councils such as the ones S. Cissokho discusses in this issue. Often, substantial changes to the chambers' funding sources and electoral procedures have been compatible with the more or less direct governmental interference in their operation.

Business associations other than chambers of commerce typically have a shorter history. As A. Badou and T. Bierschenk show in the case of Benin, they range from very transient to more enduring organizations, and they can have markedly different purposes, from highly specialized sectoral organizations with a targeted mission to those with aspirations of becoming national umbrella institutions that take it upon themselves to aggregate heterogenous collective interests.

Analytically, research on business associations has tended to suffer from a reification of the two constructs whose relationship the heuristic shorthand "business-state relations" posits. A clear-cut distinction between state and business actors may be particularly misplaced in some contexts in Africa, as the established literature on the continent has made apparent (see Bayart's (1989) notion of the rhizome state). A similar critique can also be directed at the Kenya debate, whatever its other merits may have been. In the established political science literature on business associations, M. Olson's (1965) theory of collective action has also loomed large, focusing researchers' attention on how associations were undermined by free-riders who benefited from their work and refused to contribute to advancing collective interests. From this standpoint, the ineffectiveness and "weakness" of business associations go without saying, and their resilience and accomplishments, wherever they can be established, become a source of puzzlement.

Methodologically, the dominance of quantitative approaches and reliance on written sources in research on business associations have been frequent limitations identified by some critical political scientists who have worked on the topic in the past two decades (Taylor, 2012). An example of the former (the implications of an exclusive use of quantitative methods) is the contributions of the University of Manchester's Consortium on Improving Institutions for Pro-Poor Growth (Sen and Te Velde, 2009). The latter (the limited effort to go beyond published data and press coverage) is evident in ambitious analyses of the political alignment of businesses like L. Arriola's (2012, chapter 6) comparison between Kenya and Cameroon. Consider his use of data on the duration of chamber of commerce presidents' tenure as a proxy for the relative autonomy of business vis-à-vis the state, which is premised on the assumption that statist financial controls of the private sector are associated with longer average tenures. This is one instance among many of methodological strategies that make the most of limited primary research, combining a thorough review of published sources and data with a few interviews with privileged informants. In this regard, research on business associations would do well to revisit the Kenya debate, which incorporated substantial qualitative research. To understand "BAs in practice" (Taylor, 2012: 5) would involve investigating "the ties between actors [that] are often personal or opaque which Moore and Schmitz (2008: 40-42) describe as informal, non-arm's length or 'hand-in-hand' relations" (Taylor, 
2012: 7). Ethnographic approaches, as adopted by our contributors, are the only way of meaningfully researching informal practices like these.

Against this background, our contributors demonstrate the interest in adopting a more open-ended approach to business associations that involves placing these associations within a broader set of options for the political actions facing business owners and managers. These sets of options have been referred to as "portfolios" (Schneider, 2004) or, in a terminological choice with a greater appeal for anthropologists, "repertoires" (Guyer, 2016; Offerlé, 2021). In this light, involvement in business associations appears alongside other possibilities for businesses, such as bankrolling political parties or founding thinktanks or research institutes to promote particular policy ideas or measures. As in other parts of the world, the transition from business leadership to political power tends to be far from smooth, although the electoral stakes in Madagascar in the 2000s have been summed up as "a conflict of entrepreneurs" (Pellerin, 2009; see Badou and Bierschenk for the recent case of Benin). As B. Hibou (2011: 17) has argued, based on her research on Tunisia under Ben Ali, one pitfall to avoid when analysing the factors that may push businesspeople to fund political parties and electoral campaigns is the assumption that relations between the political and economic spheres largely consist in exchanging political power or obedience for access to economic benefits.

Beyond direct or indirect involvement in party politics, in the wake of an expansion of the market for consultancy services in Africa, business owners and managers have an ample choice when it comes to funding ostensibly non-partisan organizations or hiring experts to work for them. Some such initiatives may be launched in conjunction or at cross-purposes with the work of business associations proper. There are also more individualized routes to accessing government officials by making the most of opportunities to socialize and cultivate personal ties with them (as Cissokho's article shows), and more directly, resorting to bribes or other financial inducements (as some of the large businesses operating in Mozambique do, see Manhiça). Needless to say, various options can be combined simultaneously and sequentially. Crucially, the pursuit of these options depends as much on the type of state and party system in each country (Pitcher, 2017) as on how well-endowed with different resources a given company or businessperson is. Indeed, as V. Lickert (2015) showed in an ethnographic study of French organized business in Africa, whether the pursuit of certain options is publicised (and how), while other options are shrouded in secrecy, is itself a fruitful line of research.

While the thesis that business has a privileged standing in capitalist societies remains a sensible point of departure, it is also obvious that business influence varies according to the context, going beyond a schematic understanding of dominance vs. impotence or autonomy vs. subjugation. Both what political scientists of a Marxist persuasion used to call the structural power of business (as investor, taxpayer, and employer) and its instrumental power need to be carefully documented, as the contributions to this issue convincingly demonstrate. 


\section{African variants of rentier capitalism}

Many of the businesspeople who are the focus of our contributions can be seen as actors in African variants of rentier capitalism. Recently, the concept of rentier capitalism - an economic formation dominated by rentiers, rents, and rent-generating assets - has generated a lively debate in Marxist-inspired political economy (see Piketty, 2017; Mazzucato, 2018; Christophers, 2020). These authors argue that Marx underestimated the long-term importance of rents in capitalism, and that he was mistaken (as was Keynes) when he predicted that their importance would decline over time under the increasing influence of the market and competition. This literature understands rent as "income derived from the ownership, possession or control of scarce assets and under conditions of limited or no competition" (Christophers, 2021: 3), and a rentier is the recipient of this income. The definition of rent and its distinction from what it is not - capitalist profit produced under conditions of free market competition - have been central to Western economic thought. As ethnographers, however, we remain sensitive to the difficulty of deciding empirically in given structural and situational contexts where exactly the boundary between capitalist profit and rent lies (see Bud, this issue). Marx considered only landed property and interest-bearing capital as sources of rents; however, other rentbearing assets have evolved and grown in importance over the course of time: intellectual property rights, mineral resources, platform assets, long-term service contracts and infrastructures for the delivery of communication, energy, transportation, and similar services. With the growing importance of these rents, the economies of the Global North contain rentier capitalist elements to varying degrees; in extreme cases, they dominate to such an extent that entire economies, such as the UK's, have been described as rentier capitalisms, characterised by a proprietary rather than an entrepreneurial ethos (Christophers, 2020). Rentiers are in a position to extract long-term payments for the use of scarce resources in the absence of relevant competition. They are inclined to sit on and sweat their income-generating assets rather than innovate, and in this regard they are not entrepreneurs in the Schumpeterian sense. It is not surprising, therefore, that the term carries a stigma with it: no one likes to be characterised as a rentier.

While in the Global North it is companies that hold the bulk of society's rent-generating assets, in Africa individuals play a relatively larger role, perhaps unsurprisingly given the comparatively low numbers of incorporated businesses there. Also, not all the types of rents mentioned are equally relevant to African economies. On the other hand, many African economies evolve around rents that are not given prominence by authors writing on the Global North or are mentioned only in passing. We are thinking here of financial transfers in the context of so-called development aid (Collier, 2006) and of relational capital. By this term, we mean privileged access to political elites who decide, for example, on the privatisation of state enterprises and on infrastructure contracts. B. Christophers (2021: 13) refers to asset creation here - "simply knowing how to win contracts". He also distinguishes analytically between "protecting assets" (e.g. from taxation, customs fees, and bribes, in the cases presented in this issue), which is often a function of relational 
capital, in African countries and elsewhere, and "active lobbying by major owners of rental stock". Lobbyists are thus key individuals in rentier capitalist contexts.

The concept of rentier capitalism competes with other terms with which it forms an overlapping discursive field. In recent decades, in addition to the overarching concept of "embedded capitalism" (Polanyi, 1957), terms such as "political capitalism", "crony capitalism", and "patrimonial capitalism" have been proposed. Political capitalism describes an economic and political system in which the economic and political elite cooperate for their mutual benefit - an exchange relationship that benefits both sides (Staniszkis, 1991; Holcombe, 2015). As such it is premised on the stability of the political and economic spheres, ignoring the difficulties involved in delimiting them precisely (Hibou, 2011: 17). While the term political capitalism has been used primarily to describe Eastern European transformation processes after the collapse of the Soviet Union, "crony capitalism" has been applied by some of our contributors to the countries they are studying where it highlights the social networks among political and economic players (Cissokho, Manhiça, Vampo; see also Chivangue, 2015). Recently, there has also been mention of "patrimonial capitalism" (Robinson, 2011), meaning a type of political economy in which power over it is highly personalised and economic exchange is particularistic and involves a high degree of relational capital.

We argue for the relative advantages of the concept of rentier capitalism. It is less colloquial than crony capitalism and does not have as strong normative associations as the alternatives. Crucially, it is not part of a typology that fundamentally sets Northern and Southern capitalisms apart, insofar as variants of rentier capitalism are found everywhere. Furthermore, it offers obvious connecting points to older debates on the rentier state and neo-patrimonialism (Eisenstadt, 1973).

Whichever one ultimately prefers, it should in any case be understood as an analytical term (an ideal type in the Weberian sense) that depicts aspects of a dynamic reality and does not claim to fully capture this reality within the framework of an essentialising, totalising and static typology. With these reflections, which can only be very brief here, we hope to open up a space for debate, to bring different research traditions into dialogue and to inspire further research perspectives.

None of our contributors use the term rentier. A. Badou and T. Bierschenk mention rentier capitalism, but do not develop the term further; S. Cissokho, A. Manhiça and C. Vampo speak of "crony capitalism" or capitalisme de connivence. However, in all cases (apart from A. Bud, see below) the practices of the actors they study can readily be related to the concept of rentier capitalism outlined above. A. Manhiça proposes the term "entrepreneur-broker", which he translates from the emic Portuguese term homens de contacto (contact men). During Mozambique's transition to a liberal market economy and the privatisation of state enterprises, the state became highly dependent on development aid. It is in this context that he situates the foundation of the national employer's association (CTA) with the help of development agencies. This is an institution in which the interests of the ruling political elite, businesspeople and donors intersect, and which predominantly creates opportunities for national business elites and international capital, 
with little spillover into the rest of the private sector. Entrepreneur-brokers are thus actors who use their political contacts in an "economy of influence" to gain privileged access to business opportunities. These contact men often have no equity and little business knowledge; they react opportunistically to business opportunities produced by state policy and the programmes of development agencies (see also Badou and Bierschenk). For their part, the vast majority of small and medium entrepreneurs feel excluded from these networks and complain that their interests are poorly represented by the CTA.

G. Amougou describes a similar conflict between insiders and outsiders in Cameroon. The context here is one of "emergence", a term used locally to describe policies whose overt ambition is to make Cameroon an industrial, middle-income country by 2035 . The resources and rhetoric of "emergence" as a policy platform are captured by a state elite that is allied with a certain type of economic elite, which G. Amougou, adopting a term inspired by J.-F. Médard (1992: 176), labels entrepreneur-politiciens, actors who "straddle" the economic and political sector. In other words, in the Cameroonian political reality, "emergence" does not represent a rupture. Rather, continuities with pre-existing political practices prevail, the central aim of which is to maintain the hegemony of the regime. However, many small and medium-sized entrepreneurs are excluded from these networks and demand a different definition of emergence that is more in line with their own interests.

In both Mozambique and Cameroon, the conflict between rentier capitalists and a group that feels excluded from political access lies at the centre of the analysis. Access is also the key concept in S. Cissokho's paper. In his finely grained ethnography, he is interested in actors who are members of a regional organization at the interface of the public and private sector that regulates regional trade and transport in West Africa, activities in which they themselves take an active part. In a nod to S. Laurens' (2015) "brokers of capitalism", S. Cissokho calls them "brokers of free trade" (courtiers de libre échange). Membership of this organization and participation in its regular meetings create a social proximity between entrepreneurs and state representatives; this entre-soi élitaire (a notion also used by C. Vampo) enables the former to fabriquer son accès, as S. Cissokho's interviewees put it. Meetings are occasions that make it possible to establish contacts with well-positioned public-sector actors and international development agencies that can then be used for personal goals, for example, in case of problems with customs or other state authorities. The association and its meetings provide the opportunity for collective lobbying and propagation of the principles of free trade frontstage, while in the wings (offstage), they also allow for private lobbying.

In her analysis of the Association des Femmes Chefs d'Entreprises du Togo (AFCET), which was founded in 2001 with impetus from the International Labour Office (ILO), C. Vampo identifies a very similar tension between discourses and social dynamics. The members' presentation refers to internationally fashionable progressive discourses on female empowerment and defines their association's goal as the promotion of women in the economy and society. De facto, however, the women active in the association are an 
economically, sociologically and ethnically restricted circle of well-connected women entrepreneurs who are the heirs of an older generation of Nana Benz traders. They use their membership to gain and safeguard access to the political regime and guarantee their own economic interests as well as promoting the economic visibility of women. Despite all their discourses on the innovative character of entrepreneurship, therefore, these entrepreneurs are politically and socially rather conservative - their main concern is not to rock the boat with regard either to the political regime or to conventional gender roles.

A. Badou and T. Bierschenk point to a similar collusion politico-économique in their analysis of the sprawling landscape of business associations of all shapes and sizes in Benin, where the larger business associations in particular follow the political strategies of their leaders rather than a logic of services for the benefit of their members. These organizations are in effect actors in regime politics, in la politique politicienne, with the government seeking to control them through a policy of divide and rule and political co-optation to generate party political support and minimise opposition. This continues a historical tradition to which we referred above, whereby successive governments have always sought to capture and control the private sector, a continuity that is also observed by G. Amougou in Cameroon and A. Manhiça in Mozambique. It also reveals a comparable tension between the official policy objective of developing the private sector and the government's manoeuvres to control it, which ultimately greatly weakens these associations' function of representing collective interests.

The numerous smaller associations, on the other hand, are closely interwoven into the social arena of international development policy. The establishment of these associations is often supported by development agencies (as in the cases described by C. Vampo for Togo and A. Manhiça for Mozambique, and alluded to by S. Cissokho in the case of regional trade organizations). In Benin, this has resulted in a high degree of fragmentation and thematic overlap. In addition, the limited duration of development programmes means that associations lose momentum when projects end, while others lose state support with a new government.

Finally, A. Bud's analysis of the commodification of domestic space and its coalescence with the hotel scene, on the one hand, and with film production, on the other hand, adds a welcome nuance to the theses on African variants of rentier capitalism. He shows that in a rentier capitalist-dominated economy such as Nigeria's, there may well be sectoral cases of entrepreneurial innovation and autonomous capitalist development. The innovative entrepreneurs being addressed in no way need to be found in manufacturing and production, as expected and demanded by supporters of active industrialisation policies. Rather, the focus on active industrialisation policy may block the view of a potential interplay between consumer tastes and producer techniques that can be understood as genuinely capitalist, taking us away from a purely production-oriented understanding of development. A. Bud traces how film producers in Nigeria linked Nollywood with the housing and hotel sectors, and describes both the economic and aesthetic innovative potential of these entanglements. This has produced a popular new architectural style for Nollywood houses, the transformation of homes and hotels into infrastructure for 
locations, a star culture that enabled business activities in hotel bars and the emergence of entirely new types of space that merge film sets and residences in novel ways.

Remarkably, these dynamics have played out independently of state and international funding; in A. Bud's account, this is a private sector developed without an active policy to promote it, comparable to the development of cocoa production in West Africa in the early 20th century, which happened, as it were, in a blind spot of colonial policy (Chauveau, 1997). A. Bud thus challenges the frequently cited thesis (e.g. Whitfield et al., 2015) that there has been no significant economic structural change in Africa since 1973, and he invites us to reconsider traditional understandings of economic sectors. He also reminds us how difficult it is to distinguish clearly in empirical analysis between rentbearing assets (in his example, houses and hotels) and capitalist productive assets (film industry), and that their innovative interconnectedness can be a driver of economic transformation.

\section{Paradoxes of private sector development}

Our authors also highlight other paradoxes of private sector development. First, PSD programmes do not necessarily develop the private sector as such (apart from individual enterprises), but they do promote business associations, and sometimes finance them directly. These associations are very much dominated by a certain type of businesspersons who benefit from institutional positions in these associations that give them access to the state, donors and investors. To answer the question raised at the beginning of this introduction as to how much development PSD policies ultimately produce, one might hypothesise that they may weaken rather than strengthen the private sector.

It also turns out that it would be wrong to see the relationship between governments and business associations as dyadic, as much of the current relevant literature does. In an era of internationalised economic governance that affects all African countries to varying degrees and in different forms, the dynamics of these relationships are significantly shaped by multilateral and bilateral development agencies.

Third, development agencies on the ground cannot escape the political and historical logics of the local context in which they operate in the long run. The official PSD discourse and the institutional transfers that result from it, such as business associations, can be understood as a travelling model, or "travelling blueprint", which in turn becomes subject to the "revenge of the context" (Bierschenk, 2014; Olivier de Sardan, 2021) in which it operates. The context here is one of political systems based on the ability of local political leaders to provide for clients in personalised networks through the distribution of sinecures and money derived from external aid and other resources. This echoes earlier experiences with such travelling blueprints, such as the liberalisation of foreign trade in the 1990s. In this regard, C. Boone (1994: 453) concluded that "rather than undermining the rent-seeking logic of accumulation in these countries [i.e., Senegal and Côte d'Ivoire], liberalising the external trade regime helped to reproduce it". We can go even further: our contributions show how local actors appropriate public discourses (empowerment, 
emergence and free trade) promoted by development agencies and directed towards the common good for their own ends. Rather than changing practices, these travelling blueprints therefore become resources in the pursuit of private interests. In other words, one of the paradoxical lessons to be learned from PSD "at work" - a policy which tried to push the state into the background - is that it cannot avoid engaging with the political context and local forms of governance.

\section{Anthropology and research on business and capitalism}

All the contributors to this issue have taken an anthropological approach. This is not necessarily surprising for a journal with the word anthropology in its title. We believe that this anthropological view of entrepreneurs and capitalisms in Africa is doubly productive. First, ethnography focuses on the practices of actors and takes into account their whole range - from formal to (especially) informal ones. Indeed, ethnography is the only method that can shed light on the latter type. Our contributors thus go far beyond the methodological approaches that rely almost exclusively on what M. Offerlé (2021: 28) has labelled "extractive interviews" (entretiens-prelèvements), and which dominate research on business associations. In this respect, they are a much-needed complement to quantitative approaches in development economics and the focus on policy discourse in political science research, whose blind spots they illuminate (see the postface by Asche, this issue). They also counter a tendency in political-economy debates to theorise capitalism without discussing capitalists. Second, the contributions in our issue show the productivity of the analytical concepts developed in anthropology, such as access, brokerage and clientelism. This issue therefore contains a dual appeal. In the area of entrepreneurship and capitalism research, it underlines the usefulness and productivity of anthropological approaches, and with regard to our academic discipline, it calls for further openness to the issues of economic entrepreneurship and capitalism in Africa. As we have mentioned, anthropologists have often adopted a broad notion of entrepreneurship that goes far beyond the economic, or one that focuses on the informal and precarious end of the entrepreneurial spectrum. Our contributors remind us (Althabé, 1991) that entrepreneurs in the narrower economic sense who lie outside the category of necessity entrepreneurs are also worthy subjects of anthropological study.

\section{Bibliography}

Akinyoade A., Dietz T., Uche C. (eds.), 2017, Entrepreneurship in Africa, Leiden, Brill.

Althabé G., 1991, “Désacraliser l'entreprise : un terrain ethnologique banal. Entretien par M. Sélim”, Journal des Anthropologues, $n^{\circ}$ 43-44, pp. 17-21.

Amin S., 1967, Le Développement du Capitalisme en Côte d'Ivoire, Paris, Éditions de Minuit.

Amin S., 1969, Le Monde des Affaires Sénégalais, Paris, Éditions de Minuit.

Arriola L., 2012, Multiethnic Coalitions in Africa: Business Financing of Opposition Election Campaigns, Cambridge, Cambridge University Press. 
Asche H., 2021, Regional Integration, Trade and Industry in Africa, Wiesbaden, Springer.

Barth F., 1963, "Introduction", in F. Barth (ed.), The Role of the Entrepreneur in Social Change in Northern Norway, Bergen, Scandinavian University Books, pp. 5-18.

Bayart J.-F., 1989, L'État en Afrique : la politique du ventre, Paris, Fayard.

Bierschenk T., 2014, "From the Anthropology of Development to the Anthropology of Global Social Engineering”, Zeitschrift für Ethnologie, n 139(1), pp. 73-98.

Boone C, 1994, "Trade, Taxes and Tribute: Market Liberalization and New Importers in West Africa", World Development, $\mathrm{n}^{\circ} 22(3), \mathrm{pp} .453-467$.

Chauveau J.-P., 1997, "Cocoa as Innovation: African Initiatives, Local Contexts and Agro-Ecological Conditions in the History of Cocoa Cultivation in West African Forest Lands (c. 1850 - c. 1950)", Paideuma, $\mathrm{n}^{\circ}$ 43, pp. 121-142.

Chapus Q., Berrou J.-P., Onibon Doubogan Y., 2021, "Introduction: Le retour du héros ? L'entrepreneur, itinéraire d'un concept chez les 'développeurs' en Afrique", Revue Internationale des Études du Développement, $\mathrm{n}^{\circ}$ 1, pp. 11-39.

Chivangue A., 2015, "Crony Capitalism in Mozambique: Evidence from Politicians and Businessmen Networks", Working Paper CEsA CSG, $n^{\circ} 135$, Lisbon, University of Lisbon, Lisbon School of Economics and Management.

Christophers B., 2020, Rentier Capitalism. Who Owns the Economy, and Who Pays for It?, London, Verso.

Christophers B., 2021, "Class, Assets and Work in Rentier Capitalism", Historical Materialism, pp. 1-26.

Collier P., 2006, Is Aid Oil? An analysis of whether Africa Can Absorb More Aid, World Development, 34(9), pp. 1482-1497.

Dolan C., Gordon C., 2019, “Worker, Businessman, Entrepreneur? Kenya's Shifting Labouring Subject", Critical African Studies, n¹1(3), pp. 301-321.

Eckert A., 2016, "Capitalism and Labour in Sub-Saharan Africa”, in J. Kocka (ed.), Capitalism. The Reemergence of a Historical Concept, London, Bloomsbury Academic.

Ellis S., Fauré Y.-A. (eds.), 1995, Entreprises et entrepreneurs africains, Paris, Karthala.

Elyachar J., 2005, Markets of Dispossession. NGOs, Economic Development and the State in Cairo, Durham, Duke University Press.

Eisenstadt S.N., 1973, Traditional Patrimonialism and Modern Neopatrimonialism, Beverly Hills \& London, Sage.

Evers H.-D., 1964, Kulturwandel in Ceylon. Eine Untersuchung über die Entstehung einer IndustrieUnternehmerschicht, Baden-Baden, August Lutzeyer.

Fauré Y.-A., Labazée P., 2000, Petits patrons africains: entre l'assistance et le marché, Paris, Karthala.

Forrest T.G., 1994, The Advance of African Capital. The Growth of Nigerian Private Enterprise, Edinburgh, Edinburgh University Press. 
Guyer J., 2004, Marginal Gains: Monetary Transactions in Atlantic Africa, Chicago, University of Chicago Press.

Guyer J., 2016, Legacies, Logics, Logistics: Essays in the Anthropology of the Platform Economy, Chicago, Chicago University Press.

Hall P.A., Soskice D., 2001, Varieties of Capitalism. The Institutional Foundations of Comparative Advantage, Oxford, Oxford University Press.

Hibou B., 2011, Anatomie politique de la domination, Paris, La Découverte.

Holcombe R., 2015, Political Capitalism: How economic and political power is made and maintained, Cambridge, Cambridge University Press.

Kapferer B., 1972, Strategy and Transactions in an African Factory. African Workers and Indian Management in a Zambian Town, Manchester, Manchester University Press.

Kilby P., 2003, "The Heffalump Revisited”, Journal of International Entrepreneurship, n 1, pp. 13-29.

Kitching G., 1985, "Politics, Method and Evidence in the 'Kenyan Debate', in H. Bernstein and B. Campbell (eds.), Contradictions of Accumulation in Africa. Studies in Economy and State, Beverly Hills \& London, Sage, pp. 115-152.

Kocka J. (ed.), 2016, Capitalism. The Reemergence of a Historical Concept, London, Bloomsbury Academic.

Kocka J., 2017, Capitalism. A Short History, Princeton, Princeton University Press.

Labazée P., 1991, Un terrain anthropologique à explorer: l'entreprise africaine, Cahiers d'Études Africaines, $\mathrm{n}^{\circ} 124, \mathrm{pp} .533-552$.

Laurens S., 2015, Les courtiers du capitalisme. Milieux d'affaires et bureaucraties à Bruxelles, Marseille, Agone.

Lentz C., 2017, "African Middle Classes: Lessons from Transnational Studies and a Research Agenda", in H. Melber (ed.), The Rise of Africa's Middle Class, London, Zed, pp. 17-53.

LeVine R.A., 1968, Dreams and Deeds: Achievement Motivation in Nigeria, Chicago, University of Chicago Press.

Lickert V., 2015, "Un monde en tension : légitimité et légitimation des pratiques et discours du monde des affaires français en Afrique depuis les années 1990", PhD thesis, Université Paris 1 Panthéon Sorbonne, $516 \mathrm{p}$.

Lukács G., 1970 [1968], Geschichte und Klassenbewußtsein. Studien über Marxistische Dialektik, Neuwied, Berlin, Luchterhand.

MacGaffey J., 1987, Entrepreneurs and Parasites: The Struggle for Indigenous Capitalism in Zaire, Cambridge, Cambridge University Press.

Mazzucato M., 2018, The Value of Everything. Making and Taking in the Global Economy, London, Penguin.

McClelland D., 1961, The Achieving Society, Princeton, Van Nostrand.

Meagher K., Mann L., Bolt M., 2017, Globalisation, Economic Inclusion and African Workers: Making the Right Connections, London, Routledge. 
Médard J.-F., 1992, "Le Big Man en Afrique : Esquisse d'analyse du politicien entrepreneur", L'Année Sociologique, $n^{\circ} 42$, pp. 167-192.

Moore M., Schmitz H., 2008, "Idealism, Realism and the Investment Climate in Developing Countries", IDS Working Papers, $n^{\circ} 307$, Brighton, IDS.

Muñoz J.-M., 2018, Doing Business in Cameroon. An Anatomy of Economic Governance, Cambridge, Cambridge University Press.

Naudet J.-D., 1999, Trouver des problèmes aux solutions. Vingt ans d'aide au Sahel, Paris, OECD/Club du Sahel.

Ochonu M., 2018, "Toward African Entrepreneurship and Business History", in M. Ochonu and R. Callenert (eds.), Entrepreneurship in Africa: A Historical Approach, Bloomington, Indiana University Press, pp. 1-28.

Offerlé M., 2021, Ce qu'un patron peut faire. Une sociologie politique des patronats, Paris, Gallimard.

Olivier de Sardan J.-P., 2021, La revanche des contextes. Des mésaventures de l'ingénierie sociale, en Afrique et au-delà, Paris, Karthala.

Olson M., 1965, The Logic of Collective Action, Cambridge, Harvard University Press.

Ouma S., 2019, "Africapitalism: A Critical Genealogy and Assessment", in U. Idemudia and K. Amaeshi (eds.), Africapitalism: Sustainable Business and Sustainable Development in Africa, London, Taylor \& Francis, pp. 144-157.

Pedersen P.O., McCormick D., 1999, "African Business Systems in a Globalising World", Journal of Modern African Studies, $n^{\circ}$ 37(1), pp. 109-135.

Peterson K., 2014, Speculative Markets: Drug Circuits and Derivative Life in Nigeria, Durham, Duke University Press.

Pellerin M., 2009, “Madagascar, un conflit d'entrepreneurs ? Figures de la réussite économique et rivalités politiques", Politique africaine, $\mathrm{n}^{\circ} 113$, pp. 152-165.

Piketty T., 2017, Capital in the Twenty-First Century, Cambridge, Harvard University Press.

Pitcher A., 2017, "Party System Competition and Private Sector Development in Africa", Journal of Development Studies, $\mathrm{n}^{\circ}$ 53(1), pp. 1-17.

Polanyi K., 1957, "The Economy as an Instituted Process", in M. Granovetter and R. Swedberg (eds.), The Sociology of Economic Life, Boulder, Westview, pp. 243-270.

Puente I., Schneider B.R., 2020, "Business and Development: How Organization, Ownership and Networks Matter", Review of International Political Economy, n² 27(6), pp. 1354-1357.

Rajak D., 2011, In Good Company: An Anatomy of Corporate Social Responsibility, Stanford, Stanford University Press.

Robinson N., 2011, "Russian Patrimonial Capitalism and the International Financial Crisis", Journal of Communist Studies and Transition Politics, $n^{\circ} 27(3-4)$, pp. 434-455.

Röschenthaler U., Schulz D., 2019, Cultural Entrepreneurship in Africa, London, Routledge.

Rubbers B., 2013, Le paternalisme en question : Les anciens ouvriers de la Gécamines face à la libéralisation du secteur minier katangais (RD Congo), Paris, L'Harmattan. 
Saint-Lary M., 2009, "Introduction : Des entrepreneurs entre rhétorique et action sur le monde", Bulletin de l'APAD, $\mathrm{n}^{\circ}$ 29-30, pp. 1-9.

Schneider B.R., 2004, Business, Politics and the State in Twentieth-Century Latin America, Cambridge, Cambridge University Press.

Schumpeter J.A., 1947, "The Creative Response in Economic History", Journal of Economic History, $\mathrm{n}^{\circ} 7(2)$, pp. 149-159.

Sen K., Te Velde D., 2009, "State business relations and economic growth in sub-Saharan Africa", Journal of Development Studies, n 45(8), pp. 1267-1283.

Severino J.-M., Hajdenberg J., 2016, Entreprenante Afrique, Paris, Odile Jacob.

Staniszkis J., 1991, “'Political Capitalism' in Poland”, East European Politics and Societies, n 5(1), pp. 127-141.

Sylvanus N., 2016, Patterns of Circulation: Cloth, Gender and Materiality in West Africa, Chicago, University of Chicago Press.

Taylor S.D., 2012, "Influence without Organizations: State-Business Relations and their Impact on Business Environments in Contemporary Africa", Business and Politics, $n^{\circ}$ 14(1), pp. 1-35.

Warnier J.-P., 1993, L'Esprit d'entreprise au Cameroun, Paris, Karthala.

Welker M., Partridge D., Hardin R., 2011, “Corporate Lives: New Perspectives on the Social Life of the Corporate Form: An Introduction", Current Anthropology, n 52(S3), pp. 3-16.

Whitfield L., Therkildsen O., Buur L., Kjaer A.M. (eds.), 2015, The Politics of African Industrial Policy, Cambridge, Cambridge University Press.

World Bank, 2004, Doing Business in 2004: Understanding Regulation, Washington, World Bank and Oxford University Press.

Wright S., 1994, Anthropology of Organizations, London, Routledge. 